\title{
Mesenteric vasculitis and ischaemia: every second counts
}

\author{
Sameer A Hirji, Charlotte Chung, Grace Chao, Frederick Millham
}

Department of Surgery, Brigham and Women's Hospital, Boston, Massachusetts, USA

Correspondence to Dr Sameer A Hirji, shirji@partners.org

Accepted 8 February 2018

Check for updates

To cite: Hirji SA, Chung $C$, Chao G, et al. BMJ Case Rep Published Online First: [please include Day Month Year]. doi:10.1136/bcr-2017223849

\section{DESCRIPTION}

A 65-year-old woman with past medical history significant for Perinuclear Anti-Neutrophil Cytoplasmic Antibodies (p-ANCA) vasculitis, peripheral arterial disease requiring left femoral-popliteal bypass, chronic anaemia, hypertension, hyperlipidaemia and hyponatraemia secondary to SIADH, presented to the emergency department with 1-hour history of acute onset severe, diffusely crampy abdominal pain associated with nausea, vomiting and diarrhoea. The patient reported experiencing similar but less severe symptoms 4 days prior to presentation, with gradual resolution without treatment. Additionally, the patient was admitted 2 months prior with abdominal discomfort associated with nausea, vomiting and elevated liver enzymes and was found to have mild biliary ductal dilatation without evidence of acute cholecystitis.

On evaluation, the patient was only tachycardic to 105 , but otherwise was haemodynamically stable and afebrile. Physical examination revealed a soft, mildly distended abdomen with diffuse, non-localised tenderness and no signs of peritonitis. Labs revealed elevated white cell count of $16.8 \mathrm{~K} / \mathrm{mm}^{3}$
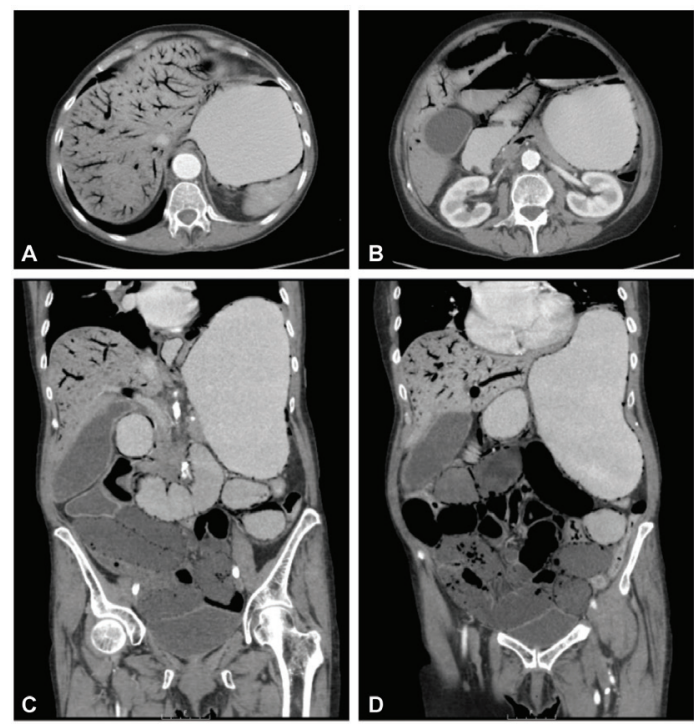

Figure 1 CT images of the abdomen and pelvis with intravenous and oral contrast, performed 4 hours after patient's presentation. Representative axial ((A) and (B)) and coronal $((C)$ and $(D))$ images demonstrate diffuse pneumatosis in the stomach and small bowel, as well as extensive mesenteric vasculature and portal venous gas. Multiple dilated loops of small bowel, measuring up to $4.7 \mathrm{~cm}$, with air-fluid levels were also visualised. No free air or free fluid was seen. The findings were consistent with small bowel obstruction with bowel ischaemia.

\section{Learning points}

- This case illustrates the rapid evolution of mesenteric infarction from a presentation of complaints out of proportion to exam all the way to frank peritonitis in merely 4 hours.

- The patient's medical history of peripheral vascular disease necessitating femoral-popliteal bypass and $p$-ANCA vasculitis suggests two potential aetiologies in this patient for arterial occlusive disease involving the mesenteric vessels. Awareness of this information may guide the emergency provider's clinical thought process and serve as warning bells for possible vascular aetiology for abdominal complaints.

- Systemic vasculitis, a heterogeneous group of clinical syndromes characterised by inflammation of blood vessels, involves the mesenteric vessels in up to $50 \%$ of patients. While most patients are asymptomatic, common symptoms include fever, nausea, vomiting, diarrhoea and bleeding. Non-specific changes were also common (78\%) and included oesophagitis, gastritis and duodenitis.More rarely, mesenteric involvement manifests as acute or chronic mesenteric ischaemia, which can cause potentially fatal bowel perforations and peritonitis. In one series of patients, $13.4 \%$ who developed mesenteric vasculitis from systemic lupus erythematosus died and $2.1 \%$ presented with intestinal perforation. Severe gastrointestinal symptoms (bleeding, perforation, infarction and/or pancreatitis) are known major predictors of mortality in polyarteritis nodosa, microscopic polyangiitis and Churg-Strauss syndrome. Such symptoms can occur on initial presentation or relapse and can manifest as benign or occlusive vasculitis. Mesenteric vasculitis only accounts for $5 \%$ of the mesenteric ischaemia, but in a patient with known vasculitis, such as our patient, or in a young patient with no predisposing factors (hypercoagulable state, cardiac arrhythmia and atherosclerotic disease), this aetiology should certainly be entertained. In our case, the patient's elevated liver enzymes and abdominal pain were attributed to potential biliary pathologies; alternatively, they could have been manifestations of her known $\mathrm{p}$-ANCA vasculitis. 
and an anion gap of 18. Provisional diagnosis included acute mesenteric ischaemia, although acute diverticulitis, bowel perforation or acute pancreatitis was considered. ${ }^{1}$

The patient was promptly treated with intravenous fluid hydration, antiemetics, analgesics and intravenous antibiotics. Abdominopelvic CT scan with oral contrast performed 4 hours after the patient's arrival (figure 1) demonstrated multiple dilated small bowel loops with extensive small bowel and gastric pneumatosis, as well as air within the portal vein and mesenteric vessels. Given concern for small bowel obstruction with extensive mesenteric infarction, ${ }^{1}{ }^{2}$ surgery was consulted. At the time of evaluation, approximately 5 hours after initial evaluation, the patient was in extremis with a rigid abdomen and in imminent respiratory failure but without altered mental status. Lactic acid was $3.2 \mathrm{mmol} / \mathrm{L}$. The patient was advised of the acute and likely lethal nature of her evolving medical condition; ultimately, she elected for exploratory laparotomy over comfort measures. The patient was taken emergently to the operating room. Upon opening of the abdomen, the intestines were found to be purple, mottled and pulseless from the ligament of Treitz to the terminal ileum, and the stomach was dusky grey. There were visible air bubbles in the gastroepiploic vessels (coeliac) and superior mesenteric artery (SMA) vessels. The mesentery was found to be pulseless. The patient was diagnosed with acute vascular occlusion resulting in extensive mesenteric infarction, and the abdomen was closed without any resection. The patient was brought to the recovery unit in critical condition and expired 2 hours later.

Contributors SH: planning, conduct, conception and design, acquisition of data, interpretation of data, manuscript writing and revisions. FM, CC and GC: conception and design, interpretation of data, manuscript writing and revisions.

Funding This research received no specific grant from any funding agency in the public, commercial or not-for-profit sectors.

Competing interests None declared.

Patient consent Obtained.

Provenance and peer review Not commissioned; externally peer reviewed.

(c) BMJ Publishing Group Ltd (unless otherwise stated in the text of the article) 2018. All rights reserved. No commercial use is permitted unless otherwise expressly granted.

\section{REFERENCES}

1 Hatemi I, Hatemi G, Çelik AF. Systemic vasculitis and the gut. Curr Opin Rheumatol 2017:29:33-8.

2 Casella G, Bronzino B, Cutrino L, et al. Vasculitis and gastrointestinal involvement. Minerva Gastroenterol Dietol 2006;52:195-214.

Copyright 2018 BMJ Publishing Group. All rights reserved. For permission to reuse any of this content visit http://group.bmi.com/group/rights-licensing/permissions.

BMJ Case Report Fellows may re-use this article for personal use and teaching without any further permission.

Become a Fellow of BMJ Case Reports today and you can:

- Submit as many cases as you like

- Enjoy fast sympathetic peer review and rapid publication of accepted articles

- Access all the published articles

Re-use any of the published material for personal use and teaching without further permission

For information on Institutional Fellowships contact consortiasales@bmjgroup.com

Visit casereports.bmj.com for more articles like this and to become a Fellow 